\title{
ANALISIS KINERJA KEUANGAN UNTUK MENILAI KEUNGGULAN BERSAING PADA BANK SYARIAH MANDIRI INDONESIA
}

\author{
Asyraf Mustamin ${ }^{1}$, Ismawati ${ }^{2}$, Tri Mulato ${ }^{3}$ \\ 1UIN Alauddin Makassar, asyraf_citizen@windowslive.com \\ ${ }_{2}^{2}$ UIN Alauddin Makassar, ismawatiabbas77@gmail.com \\ ${ }^{3}$ UIN Alauddin Makassar, trimsiuii@yahoo.co.id
}

\begin{abstract}
ABSTRAK
Penelitian ini bertujuan untuk mengungkap pelaksanaan penyajian laporan keuangan yang disajikan oleh Bank Mandiri Syariah Indonesia secara menyeluruh yaitu dari sisi kinerja keuangan yang menjadi salah satu dasar keunggulan bersaing bagi perusahaan yaitu dari aspek keuangan. Studi ini dilaksanakan dengan menganalisis Laporan keuangan Bank Mandiri Syariah selama tiga tahun yaitu tahun 2013-2015. Adapun analisis yang dignakan untuk menilai kinerja keuangan Bank Mandiri Syariah ialah analisis rasio analisis likuiditas, Analisis Rasio likuiditas dipilih karena merupakan rasio untuk mengukur kemampuan dalam memenuhi kewajiban jangka pendeknya pada saat ditagih oleh suatu perusahaan. Dengan kata lain dapat membayar kembali pencairan dana depositnya pada saat ditagih serta dapat mencukupi permintaan kredit yang telah diajukan. Hasil penelitian ini menunjukkan bahwa kinerja keuangan Bank Mandiri Syariah cukup baik dan mampu memenuhi kebutuhannya dengan rasio likuiditas yang ada padahal Bank Mandiri syariah tidak menjalankan sistem bunga pada pengoprasiannya serta tidak bergerak dalam sektor produksi.
\end{abstract}

Kata-kata kunci : Kinerja Keuangan, Keunggulan Bersaing, Laporan Keuangan.

\section{ABSTRACT}

This study aims to reveal the implementation of the presentation of financial statements presented by Bank Mandiri Syariah Indonesia as a whole, in terms of financial performance which is one of the bases of competitive advantage for companies, namely from the financial aspect. This study was conducted by analyzing the financial statements of Bank Mandiri Syariah for three years, namely 2013-2015. The analysis used to assess the financial performance of Bank Mandiri Syariah is the analysis of the analysis of liquidity ratios. The analysis of liquidity ratios was chosen because it is a ratio to measure the ability to meet short-term obligations when billed by a company. In other words, it can repay the disbursement of the deposit when it is billed and can meet the credit request that has been submitted. The results of this study indicate that Bank Mandiri Syariah's financial performance is quite good and is able to meet its needs with the existing liquidity ratio even though Bank Mandiri Syariah does not run an interest system in its operations and does not oriented in the production sector.

Keywords: Financial Performance, Competitive Advantage, Financial Statements. 


\section{PENDAHULUAN}

Dalam perkembangannya hingga saat ini keuangan Islam masih berada pada tahap awal pertumbuhannya dan menghadapi banyak tantangan. Salah satu tantangan terbesar bagi industry keuangan Islam adalah kurangnya tenaga-tenaga yang terampil yang memiliki pengetahuan yang mendalam mengenai kaidah-kaidah dan prinsip-prinsip syariah disamping itu juga memiliki pengetahuan yang handal mengenai keuangan, oleh sebab itu dalam rangka memastikan pertumbuhan keuangan dan ekonomi Islam adalah untuk memastikan keberlanjutan sumber daya manusia merupakan hal utama agar dapat melahirkan para professional yang berkualifikasi tinggi. Mengembangkan para ahli dalam bidang ini pada gilirannya akan dapat menghasilkan inovasi keberlanjutan berupa produk-produk dan jasa-jasa baru keuangan Islam, serta perbaikan pada produk-produk dan jasa-jasa yang ada guna memenuhi dan melayani kebutuhan-kebutuhan masyarakat secara efektif dan efisien.

Agar ini dapat terjadi maka pihak-pihak yang mempunyai potensi dan masyarakat umum harus memiliki akses informasi tentang jasa-jasa dan produk-produk keuangan Islam. Sebuah program pendidikan yang ekstensif dan terstruktur merupakan kunci untuk meningkatkan kualitas kesadaran pelanggan dan bisnis yang berkaitan dengan permasalahan tersebut. Selain itu semua pihak yang terlibat dalam didalam berbagai transaksi keuangan Islam perlu memahami dan mengapresiasi karakteristik dan fakta unik dari semua factor keuangan Islam, yang mencakup perbankan Islam, takaful, pasar modal Islam, dan pasar uang Islam. Pemahaman mengenai pelaksanaan transaksi-transaksi keuangan Islam akan mengarah pada ketepatan pelaksanaan kontrak-kontrak keuangan Islam yang mencerminkan asas-asas syariah. Untuk menyebarluaskan informasi keuangan Islam secara efektif dan efisien, selain memanfaatkan kemajuan teknologi informasi dan komunikasi.

Salah satu pilar penting dalam keuangan dan perekonomian baik itu konvensional maupun keuangan Islam ialah laporan keuangan, bagaimana keadaan suatu instansi, bangsa, perusahaan, atau apapun yang berkaitan dengan bisnis secara garis besar kemajuan dan potensinya dapat dilihat dari laporan keuangannya. Dalam penyusunan laporan keuangan dibutuhkan keterampilan yang baik dan pengetahuan mumpuni utamanya 
dalam bidang akuntansi untuk mendukung penyusunan dan penyajian laporan keuangan yang baik dan dapat dipahami.

Dalam penyusunan laporan keuangan peran akuntansi merupakan hal yang paling utama namun saat ini seiring dengan perkembangan keuangan dan perbankan syariah maka diperlukan pula suatu sistem akuntansi yang juga dapat mendukung perkembangan perekonomian Islam tersebut yakni akuntansi syariah, kebedaraan dan peran akuntansi syariah beberapa kalangan menanyakan mengenai urgensi akuntansi syariah karena menganggap bahwa akuntansi syariah dan akuntansi yang berlaku secara umum sama saja dan menanyakan dimana letak perbedaannya. Ungkapan tersebut adalah wajar, walaupun tidak seluruhnya benar, secara sederhana pengertian akuntansi syariah dapat dijelaskan melalui akar kata yang dimilikinya yaitu akuntansi dan syariah, defenisi bebas dari akuntansi adalah identifikasi transasksi yang kemudian diikuti dengan kegiatan pencatatan, penggolongan, serta pengikhtisaran transaksi tersebut sehingga menghasilkan laporan keuangan yang dapat digunakan untuk mengambil keputusan. Sedangkan definisi bebas dari syariah adalah aturan yang ditetapkan oleh Allah Swt untuk dipatuhi oleh manusia dalam menjalani segala aktivitas kehidupan di dunia.

Adapun defenisi akuntansi (konvensional) menurut American Accounting Assosiation (AAA) adalah the identification, recording, classification, interpreting and communication economic events to permit users to make informed decision. Sedangkan Akuntansi Syariah adalah the "accounting process" which provides appropriate information (not neccecary limited to financial data) to stakeholders of an entitiy which will enable them to ensure that the entity is continuously operating within the bounds of the Islamic shari'ah aand delivering on its sosioeconomics objectives (Nurhayati, 2013).

Dari perbedaan di atas, informasi yang disajikan oleh akuntansi syariah untuk pengguna laporan lebih luas tidak hanya data finansial juga mencakup aktivitas perusahaan yang berjalan sesuai dengan syariah serta memiliki tujuan sosial yang tidak terhindarkan dalam Islam misalnya dengan adanya kewajiban zakat. Akuntansi syariah juga dibutuhkan dan berbeda dengan akuntansi konvensional mengingat yang dilahirkan dari system nilai dan aturan yang berbeda. Oleh karena itulah akuntansi syariah diperlukan untuk mendukung kegiatan yang harus dilakukan sesuai dengan syariah karena tidak mungkin dapat menerapkan akuntansi yang 
sesuai dengan syariah jika transaksi yang akan dicatat oleh proses akuntansi tersebut tidak sesuai dengan syariah.

Di Indonesia sendiri penyajian laporan keuangan telah diatur oleh Ikatan Akuntan Indonesia pada pernyataan standar akuntansi keauangan termasuk bank syariah. Laporan keuangan itu sendiri digunakan agar dapat mengukur bagaimana berjalannya kinerja perusahaan namun peneliti disini ingin melihat bagaimana penyajian laporan keuangan yang disajikan oleh bank syariah di Indonesia dan kesesuaiannya dengan standar akuntansi yang telah ditetapkan serta bagaimana analisis rasionya karena bank syariah sendiri memiliki pembiayaan dan aturan tersendiri yang berbeda dengan bank konvensional sehingga mampu bertahan dengan metode pembiayaannya sendiri, oleh karena itu peneliti mendeskripsikannya dengan penelitian yang berjudul "Analisis kesesuaian laporan keuangan berdasarkan SAK dan kinerja keuangan untuk menilai keunggulan bersaing pada Bank Syariah Mandiri Indonesia".

Setiap penelitian memiliki tujuan dan kegunaan tertentu. Secara umum penelitian memilki tujuan yaitu yang bersifat penemuan, pembuktian, dan pengembangan (Sugiyono, 2012). Sebuah topik yang diteliti, di antaranya karena ada kegelisahan akademik (academic problem) yang ditemukan oleh peneliti. Kegelisahan akademik atau disebut dengan masalah yang dapat diartikan kesenjangan antara harapan akan sesuatu yang seharusnya ada (das sollen) dengan kenyataan yang ada (das sein) Kegelisahan akademik tersebut diharapkan untuk mencari pemecahannya dalam menemukan pengetahuan baru dan menambah perbendaharaan ilmu pengetahuan sebagai media untuk kemajuan peradaban umat manusia. (Margono, 2003).

Penelitian ini sebagaimana penelitian lainya dimulai dengan menentukan masalah atau identifikasi masalah. Permasalahan merupakan titik tolak keseluruhan penelitian. Usaha memperoleh jawaban atas permasalahan tersebut merupakan tujuan dari penelitian yang akan dilakukan. Ini berarti, identifikasi masalah dan batasan masalah merupakan suatu pedoman umum dalam penelitian sebagai landasan untuk menentukan arah dari peneliti tersebut. Fokus penelitian ini adalah bagaimana kinerja keuangan Bank Syariah yang memliki akad pembiayaan perbankan syariah tersendiri, serta bagaimana proses penyajian laporan keuangan berdasarkan Pernyataan Standar Akuntansi Keuangan Indonesia 
tentang keuangan syariah. Maka pertanyaan paling mendasar dalam penelitian ini adalah Bagaimana rasio likuiditas kinerja keuangan untuk menilai keunggulan bersaing perbankan pada Bank Syariah Mandiri Indonesia.

\section{METODE PENELITIAN}

Jenis penelitian dalam tesis ini meliputi kombinasi antara penelitian pustaka (library research) dan penelitian lapangan (field research) (Azwar, 2000) dengan metode kualitatif (qualitative method) yang dilakukan secara deskriptif analisis, karena penelitian ini memberikan gambaran tentang hasil penelitian dengan mendeskripsikan data-data aktual yang diperoleh di lapangan. (Moeloeng, 2010).

Objek penelitian ini peneliti melaukukan penelitian Analisis Laporan Keuangan berdasarkan Pernyataan Standar Akuntansi Keuangan Indonesia tentang penyajian laporan keuangan bank syariah pada bank Mandiri Syariah dengan periode laporan keuangan tiga tahun terakhir yaitu 2013-2015. Dalam pemilihan suatu perusahaan/bank, pada penelitian ini peneliti memilih untuk melakukan penelitian pada salah satu bank syariah terbesar di Indonesia yaiti Bank Mandiri Syariah. Sumber data yang dimaksud dalam penelitian ini adalah subyek dari mana data diperoleh (Neong, 1998) Sumber data dalam penelitian ini menggunakan dua jenis sumber data yaitu:

a. Sumber data primer, adalah data yang diperoleh secara langsung dari data Laporan Keuangan kaitannya dengan masalah yang akan diteliti. Bersumber dari studi lapangan berupa informasi yang berasal dari Bank Mandiri Syariah.

b. Sumber data sekunder adalah merupakan sumber data yang tidak lansung dari informan atau data tambahan yang digunakan yang berupa dokumenter yang bersumber dari buku-buku yang membahas Laporan Keuangan Perbankan Syariah syariah, hasil-hasil penelitian, jurnal, majalah, media cetak, dan dokumen-dokumen lainnya yang berkaitan dengan penelitian ini.

Dalam hal ini segala sumber informasi media di atas yang

mendukung kerja peneliti. Metode Pengumpulan Data. Proses pengumpulan data peneliti menggunakan data pustaka dan data lapangan. Teknik pengumpulan data dilakukan dengan cara observasi, wawancara, 
dan dokumentasi.

\section{HASIL DAN PEMBAHASAN}

1. Rasio Likuiditas Bank Syariah Mandiri Indonesia

\begin{tabular}{|c|c|c|c|c|}
\hline \multirow{12}{*}{$\begin{array}{c}\text { Rasio } \\
\text { Likuiditas }\end{array}$} & Tahun & Aset Lancar & Kewajiban Lancar & Rasio Lancar \\
\hline & 2013 & $62,970,276,498,257$ & $9,954,132,275,107$ & 6.32 \\
\hline & 2014 & $74,769,956,747,081$ & $7,680,757,927,860$ & 9.73 \\
\hline & 2015 & $80,476,578,947,455$ & $9,069,445,146,551$ & 8.87 \\
\hline & Tahun & kas + piutang & kewajiban lancar & Rasio cepat \\
\hline & 2013 & $33,807,039,781,732$ & $9,954,132,275,107$ & 3.39 \\
\hline & 2014 & $34,167,970,294,860$ & $7,680,757,927,860$ & 4.44 \\
\hline & 2015 & $36,418,129,735,518$ & $9,069,445,146,551$ & 4.01 \\
\hline & Tahun & kas dan setara kas & kewajiban lancar & Rasio kas \\
\hline & 2013 & $1,444,785,308,390$ & $9,954,132,275,107$ & 0.14 \\
\hline & 2014 & $1,513,579,952,064$ & $7,680,757,927,860$ & 0.19 \\
\hline & 2015 & $1,611,124,530,574$ & $9,069,445,146,551$ & 0.17 \\
\hline
\end{tabular}

2. Pembahasan Rasio Likuiditas

a. Rasio lancar

Rasio lancar pada tahun 2014 lebih baik jika dibandingkan dengan rasio lancar pada tahun 2013 dan tahun 2015, jika dibandingkan pada tahun 2013 rasio lancar yang dicatatkan oleh Bank Syariah Mandiriadalah 6.32 dan pada tahun 2015 adalah sebesar 8.87 jika dibandingkan dengan tahun 2014 yang memperoleh angka 9.97 secara garis besar tingkat likuiditas rasio lancar Bank Syariah Mandiridari tahun 2013-2015 terbilang sangat baik.

b. Rasio cepat.

Rasio cepat tahun 2014 lebih baik jika dibandingkan dengan tahun 2013 dan 2015 namun jika dilihat secara keseluruhan maka posisi total kewajiban lancar seluruhnya di tiga tahun tersebut dapat "ditutup" sepenuhnya oleh aset sangat lancar oleh karena itulah dalam hal ini kinerja perusahaan dalam hal rasio sangat lancar cepat dapat dikategorikan sangat baik dari tahun ke tahun. 
c. Rasio kas

Begitu juga untuk cash rasio/rasio kas yaitu kemampuan seberapa besar uang kas atau setara kas yang tersedia untuk membayar jangka pendek pada tahun 2014 merupakan tahun tertinggi kemampuannya dibandingkan dengan tahun yang lainnya yaitu sebesar 0.19 jika dibandingkan dengan tahun 2013 yaitu 0.14 dan 2016 yaitu 0.17 disini dapat dikatakan bahwa perusahaan cenderung dalam kondisi yang cukup baik untuk menggunakan kas atau setara kas untuk membayar kewajibannya.

\section{Keunggulan Bersaing Bank Syariah Mandiri Indonesia}

Keunggulan bersaing menurut Porter adalah kemampuan suatu perusahaan untuk meraih keuntungan ekonomis di atas laba yang mampu diraih oleh pesaing di pasar dalam industri yang sama. Perusahaan yang memiliki keunggulan kompetitif senantiasa memiliki kemampuan dalam memahami perubahan struktur pasar dan mampu memilih strategi pemasaran yang efektif. Studi yang dilakukan Porter selanjutnya menetapkan strategi generik yang diklasifikasikan dalam tiga kategori, yaitu cost leadership, diferensiasi, dan focus disini peneliti berfokus pada aspek keuangannya.

Secara keseluruhan rasio untuk Bank Syariah Mandiri memiliki kinerja keuangan yang baik namun jika dilihat dari grafik tahun ke tahun maka rasio kinerja pada Bank Syariah Mandiri cukup baik dan stabil dan pada tahun 2014 menjadi tahun yang terbaik bagi bank tersebut jika dibandingkan dengan tahun sebelumnya maupun tahun setelahnya. Berdasarkan hasil analisis rasio dan interpretasinya diatas dapat disimpulkan bahwa kemampuan Bank Syariah Mandiri dalam hal keunggulan bersaingnya cukup baik dari sisi keuangan padahal Bank Syariah Mandiri tidak memakai system bunga pada kegiatan operasionalnya namun tetap dapat memenuhi kebutuhannya sendiri ini membuktikan bahwa system islam dapat juga bersaing meskipun tidak menggunakan system konvensional sekaligus dapat menjalankan kegiatan perbankan tanpa melanggar syariat agama.

Dari analisis rasio tersebut diatas Bank Syariah Mandiri rata-rata menunjukkan kinerja yang baik meskipun pada beberapa komponen agak rendah, namun hal tersebut masihlah wajar mengingat kegiatan operasional 
Bank Syariah Mandiriyang tidak bergerak pada sector produksi dan tidak menggunakan system riba ditambah lagi nasabahnya yang belum terlalu banyak seperti bank konvensional pada umumnya dikarenakan berdirinya Bank Syariah Mandiriterpaut jauh dengan mank konvensional sehingga laba yang dihasilkan masih tergolong sedikit sehingga juga berberpengaruh pada analisis rasio yang dihasilkan.

Kemampuan keunggulan bersaing Bank Syariah Mandiri dari aspek keuangan ini seperti dikemukakan sebelumnya tergolong cukup baik ini juga terbukti dengan diraihnya beberapa penghargaan oleh bank tersebut selama sepuluh tahun terakhir salah satunya adalah penghargaan the most trusted company yang menunjukkan kepercayaan nasabah kepada bank mandiri syariah. Disini dapat dilihat bahwa Bank Syariah Mandiri telah memiliki modal yang bagus untuk mengembangkan bisnisnya yaitu kepercayaan dari masyarakat ditambah dengan hasil analisis rasio ini yang menunjukkan kinerja keuangannya cukup baik sehingga keunggulan bersaing Bank Syariah Mandiritidak hanya dalam hal kinerja keuangan untuk mampu memenuhi kebutuhannya sendiri tetapi juga kepercayaan dari masyarakat sehingga prospek Bank Syariah Mandirikedepannya sangat menjanjikan. Selain itu ada juga beberapa hal yang ditemukan oleh peneliti mengenai hal-hal lain yang mempengaruhi keunggulan bersaing pada Bank Syariah Mandiribaik secara internal maupun eksternal ialah sebagai berikut.

\section{Prospek Usaha Perusahaan}

Situasi dan kondisi sosial politik pada tahun 2016 diperkirakan akan tetap stabil dan terkendali, kondisi ini didukung dengan prediksi BI bahwa pertumbuhan konomi tahun 2016 akan lebih baik dari perekonomian saat ini yang mengalami perlambatan. Penetapan Paket Kebijakan pemerintah yang baru dibidang ekonomi diharapkan dapat meningkatkan kondisi perekonomian yang saat ini masih belum cukup menggembirakan.

Belum terealisasinya beberapa program pemerintah sampai dengan kuartal III 2015, memunculkan isu reshuffle kabinet yang akan dilakukan oleh pemerintah. Namun demikian, isu tersebut tidak mengganggu jalannya kinerja pemerintah. Sementara itu gelombang pertama pelaksanaan Pilkada serentak akan dilaksanakan pada Desember 2015. Pilkada akan berlangsung di 269 daerah terdiri atas 9 provinsi, 36 kota, dan 
224 kabupaten atau sekitar 53\% dari total 537 jumlah propinsi dan kabupaten/kota di Indonesia. Pelaksanaan Pilkada tersebut diperkirakan akan terlaksana sesuai rencana dan tetap terkendali. Musim kemarau yang panjang sebagai dampak El Nino telah menimbulkan kekeringan di berbagai wilayah Indonesia dan menyebabkan lahan sawah mengalami puso sehingga gagal panen tidak bisa terhindarkan. Hal ini menyebabkan pemerintah melakukan impor beras untuk cadangan pasokan. Faktor musibah bencana asap kebakaran hutan pada semester II 2015 yang sempat mengganggu jalannya akivitas ekonomi dan sosial masyarakat di beberapa wilayah Indonesia berangsur membaik dan diharapkan dapat segera normal seperti sedia kala.

\section{Kondisi Makro Ekonomi}

Sampai dengan kuartal akhir tahun 2015, kondisi ekonomi global masih belum menunjukkan situasi yang melegakan. Bahkan, nilai tukar rupiah yang telah ditetapkan dalam nota keuangan RAPBN tahun 2016 sebesar Rp13.400-Rp14.400 direvisi BI menjadi Rp13.400-Rp13.900 per USD. Kondisi ekonomi global dan harga komoditas primer diperkirakan mencapai titik terendah pada tahun ini. Pasar keuangan menghadapi beberapa risiko perekonomian yang berasal dari eksternal maupun domestik. Dari sisi global, membaiknya ekonomi AS di tengah lemahnya ekonomi global terutama Tiongkok menciptakan kondisi yang meragukan, seiring dengan ketidakpastian The Fed yang membatalkan kenaikan suku bunga dari posisi 0,25\% melalui Federal Open Market Committee (FOMC). Asumsinya apabila The Fed menaikkan suku bunga acuan, modal yang keluar dari AS selama kebijakan pelonggaran likuiditas ke banyak negara akan kembali ke AS. Dampaknya, pasar modal dan pasar valuta asing berbagai negara akan terkoreksi.

\section{Kondisi Mikro Ekonomi}

Di sisi domestik, belanja pemerintah perlu dicermati karena menentukan implementasi proyek-proyek infrastruktur yang berperan penting dalam menjaga optimisme terhadap prospek perekonomian. Faktor-faktor yang mempengaruhi proyeksi keuangan Bank adalah: pertumbuhan ekonomi, tingkat inflasi, nilai tukar Rupiah, dan BI rate. Pertumbuhan ekonomi pada triwulan III 2015 yang meningkat didukung oleh akselerasi belanja pemerintah seiring dengan realisasi proyek-proyek 
infrastruktur dan Paket Kebijakan Ekonomi yang dikeluarkan oleh pemerintah. BI memperkirakan pertumbuhan ekonomi 2015 mencapai 4,7\%-5,1\% (yoy). Sedangkan untuk tahun 2016 BI memprediksikan pertumbuhan ekonomi berada pada kisaran 5,2\%-5,6\%. Hal ini terkait dengan semakin meningkatnya realisasi proyek-proyek infrastruktur pemerintah yang akan meningkatkan aktivitas dunia usaha sehingga dapat menambah serapan tenaga kerja dan meningkatkan konsumsi rumah tangga.

Sedangkan Inflasi pada akhir tahun 2015 telah terkendali, secara keseluruhan berada di titik tengah sasaran inflasi 2015 yaitu 4\%. Di sisi domestik, tekanan inflasi dari sisi permintaan diprakirakan relatif moderat sejalan dengan pertumbuhan ekonomi yang di bawah tingkat potensialnya dan masih rendahnya utilisasi kapasitas produksi. Nilai tukar rupiah mengalami tekanan seiring penguatan Dollar AS terhadap hampir semua mata uang. Namun demikian, Pemerintah optimistis untuk dapat menjaga stabilitas nilai tukar rupiah sesuai dengan fundamentalnya, sehingga dapat mendukung stabilitas makro ekonomi dan penyesuaian ekonomi ke arah yang lebih sehat dan berkesinambungan.

BI tetap mempertahankan BI Rate sebesar 7,50\%. Langkah tersebut untuk menjaga agar inflasi berada dalam titik tengah sasaran inflasi $4 \pm 1 \%$ pada 2015 dan 2016. BI mengambil keputusan tersebut sebagai langkah antisipasi kemungkinan kenaikan suku bunga Bank Sentral AS. BI mengarahkan kebijakan jangka pendek pada langkah-langkah mejaga stabilitas nilai tukar dengan operasi moneter, memperkuat pengelolaan permintaan dan penawaran valas, serta melanjutkan langkah pendalaman pasar uang. BI juga terus memperkuat bauran kebijakan moneter dan makro prudensial untuk memastikan tetap terjaganya stabilitas makro ekonomi, khususnya stabilitas nilai tukar, dan stabilitas sistem keuangan dalam mendukung kesinambungan perekonomian.

Dengan kondisi tersebut di atas, Bank masih memiliki optimisme yang tinggi memenangkan persaingan bisnis perbankan. Hal ini, karena industri perbankan syariah diyakini memiliki prospek jangka panjang yang sangat baik hingga satu dekade ke depan. Saat ini, Indonesia merupakan kiblat baru industri keuangan syariah di dunia. Hal itu didasari oleh struktur masyarakat Indonesia yang memiliki penduduk muslim terbesar. 
7. Hal-Hal yang Berpotensi Berpengaruh terhadap Kelangsungan Usaha

Sampai dengan tahun 2015, BSM tidak memiliki hal-hal yang berpengaruh signifikan terhadap kelangsungan usaha. Informasi penting untuk mendukung kondisi tersebut sebagai berikut:

a. Berdasarkan perhitungan manajemen pada tanggal 31 Desember 2015 dan 2014, Bank memiliki rasio kecukupan penyediaan modal minimum (KPMM) masing-masing sebesar 12,85\% dan 14,12\%.

b. Pada tanggal 31 Desember 2015 dan 2014 Bank memiliki rasio Aset Produktif yang Diklasifikasikan (APYD) terhadap jumlah asset produktif masing-masing sebesar 0,94 dan 0,94.

c. Pada tanggal 31 Desember 2015 dan 2014, rasio piutang, pinjaman qadh dan pembiayaan yang nonperforming (gross) terhadap jumlah piutang,pinjaman qardh, dan pembiayaan adalah masing-masing sebesar $6,14 \%$ dan $6.97 \%$, sedangkan rasio piutang, pinjaman qardh, dan pembiayaan yang Nonperforming (net) terhadap jumlah piutang, pinjaman qardh dan pembiayaan adalah masing-masing sebesar $4,09 \%$ dan $4,42 \%$.

d. Dalam laporan Batas Maksimum Pemberian Kredit (BPMK) yang disampaikan Bank kepada Bank Indonesia pada tanggal 31 Desember 2015 tidak terdapat piutang dan pembiayaan yang melampaui atau melanggar ketentuan BMPK.

\section{Asumsi Dasar Kelangsungan Usaha}

Asumsi tersebut berlandaskan pada posisi BSM, jika dilihat dari analisis kekuatan (strengths) dan kelemahan (weaknesses), peluang (opportunities) dan hambatan (threatment), serta identifikasi.

a. Kekuatan BSM

1) Dukungan induk perusahaan yang kuat dan sinergi dengan Mandiri Group

2) Sumber Daya Manusia yang lebih dari $50 \%$ berusia berusia di bawah 40 tahun.

3) Dipercaya oleh masyarakat yang ditandai dengan penghargaan lembaga eksternal berupa The Most Trusted Companies dan Service Excellence dan penghargaan lain. 
4) Merupakan bank syariah dengan pangsa pasar tertinggi untuk aset, dana pihak ketiga, dan pembiayaan

b. Peluang BSM

1) Tingginya populasi Muslim di Indonesia

2) Tingginya potensi pasar perbankan syariah yang ditandai dengan masih kecilnya pangsa pasar bank syariah dibandingkan bank konvensional yang di bawah $5 \%$

3) Mengembangkan bisnis Bank berdasar akad yang spesifik di bank syariah seperti gadai, Ijarah Muntahiyya bit Tamlik, dan Musyarakah Mutanaqisah.

\section{SIMPULAN}

Berdasarkan hasil analisis rasio dan interpretasinya diatas dapat disimpulkan bahwa kemampuan bank mandiri syariah dalam hal keunggulan bersaingnya cukup baik dari sisi keuangan padahal bank mandiri syariah tidak memakai system bunga pada kegiatan operasionalnya namun tetap dapat memenuhi kebutuhannya sendiri ini membuktikan bahwa system islam dapat juga bersaing meskipun tidak menggunakan system konvensional sekaligus dapat menjalankan kegiatan perbankan tanpa melanggar syariat agama. Disamping itu Laporan keuangan Bank Mandiri Syariah untuk tahun 2013-2015 memiliki kinerja yang baik dan juga keunggulan bersaingnya yang cukup baik ditambah dengan penghargaan sebagai the most trusted company sehingga bank ini juga memiliki keunggulan dalam hal kepercayaan oleh masyarakat meskipun jika unsur laba maupun laba operasional yang digunakan untuk mengukur rasio cukup rendah namun hal tersebut dinilai masih wajar karena kegiatan Bank Mandiri Syariah yang fokus operasionalnya bukan pada sektor industri namun pada sektor jasa.

Hasil penelitian ini menurut pandangan peneliti harus dikembangkan lebih dalam lagi dengan mengungkapkan pendekatan yang berbeda, hasil penelitian ini jika diibaratkan dengan teori Dramaturgi maka belum sampai cakupannya untuk mengungkapkan "panggung belakang" dari perusahaan oleh karena itulah peneliti merekomendasikan untuk melakukan penelitian lanjutan mengenai keuangan bank mandiri syariah dengan pendekatan yang lebih dalam lagi untuk dapat mengungkap "panggung belakang" bank mandiri syariah dalam kaitannya dengan 
fungsi pertanggung jawaban bank mandiri syariah kepada pengguna informasi maupun kepada Tuhan.

\section{DAFTAR RUJUKAN}

AAOFI. (2003). Accounting dan Organization for Islamic Financial Institution. Bahrain: AAOFI.

Ali, M. (1985). Penelitian Kependidikan Prosedur dan Strategi. Bandung: Angkasa.

Alimuddin, M. R. (2016). Ideologi Akuntansi Islam. Jakarta: Rajawali Pers.

Amiruddin, Z. A. (2012). Pengantar Metode Penelitian Hukum. Jakarta: Rajawali Pers.

Antonio, S. (2001). Bank Syariah: dari teori ke praktek. Jakarta: Gema Insani.

Ardiyos. (2006). Kamus Standar Akuntansi. Jakarta: Citra Harta Prima.

Ascarya. (2008). Produk dan Akad Bank Syariah. Jakarta: Raja Grafindo Persada.

Azwar, S. (1998). Metode Penelitian. Yogyakarta: Pustaka Pelajar.

Azwar, S. (2004). Metode Penelitian. Yogyakarta: Pustaka Pelajar.

Bungin, B. (2009). Analisis Data Kualitatif: Pemahaman dan metodologis ke Arah Penguasaan Aplikasi. Jakarta: Rajawali Pers.

Fraser, L. M. (2008). Memahami Laporan Keuangan. Jakarta: Indeks.

Harahap. (2008). Teori Akuntansi. Jakarta: Rajawali Pers.

Husaini Usman, P. (2008). Metodologi Penelitian Sosial. Jakarta: Bumi Aksara.

IAI. (2009). Standar Akuntansi Keuangan. Jakarta: Salemba Empat.

Irham, F. (2012). Analisis Laporan Keuangan. Bandung: Alfabeta.

ISRA. (2015). Sistem Keuangan Islam, Prinsip \& Operasi. Jakarta: Rajawali Pers.

Kasmir. (2008). Analisis Laporan Keuangan. Jakarta: Rajawali Pers.

Kemenag. (2014). Al Qur'an dan Terjemahannya. Bandung: Jumanatul Ali.

KR. Subramayam, J. J. (2010). Analisis Laporan Keuangan. Jakarta: Salemba Empat.

Laidin, A. (2015). Sistem Keuangan Islam. Malaysia: ISRA.

Lili, S. (2002). dasar-dasar akuntansi. Jakarta: Bumi aksara.

Maimunah, S. (2015). Pengaruh Analisis Financial Leverage terhadap peningkatan earnig per share. JIAFE, 38-43.

Mardani. (2015). Aspek Hukum Lembaha Keuangan Syariah di Indonesia. Jakarta: Kencana.

Margono. (2003). Metodologi Penelitian Pendidikan. Jakarta: PT. Rineka Cipta.

Mirzha, T. (1999). Konsep Economic Value Added: Pendekatan untuk menentukan Nilai Riil Manajemen. Jakarta: Usahawan Publisher.

Moeleong, L. J. (2010). Metodologi Penelitian Kualitatif. Bandung: Remaja rosdakarya.

Muhajir, N. (1998). Metode Penelitian Kualitatif. Yogyakarta: Rake Selatan.

Muhammad. (2004). Manajemen dana Bank Syariah. Yogyakarta: Ekonisisa UII.

Muhammad. (2005). Manajemen Bank Syariah. Yogyakarta: UPP AMP YKPN.

Muhammad, R. (2008). Akuntansi Keuangan Syariah. Yogyakarta: P3EI. 
Munawir. (2010). Analisa Laporan Keuangan. Yogyakarta: Liberty.

Musim, I. (t.thn.). Sahih Imam Muslim.

Nata, A. (2004). Metodologi Studi Islam. Jakarta: Rajagrafindo Persada.

Nurhayati. (2013). Akuntansi Syariah di Indonesia. Jakarta: Salemba Empat.

Penyusun, T. (2013). Pedoman Karya Tulis,Skripsi, Tesis, Disertasi, dan Laporan Penelitian . Makassar: UIN Alauddin Press.

Prihadi. (2009). Investigasi Laporan Keuangan \& Analisis Rasiao Keuangan. Jakarta: PPM Manajemen.

Rama, A. (2015). Analisis determinan pengungkapan islamic social reporting: Studi kasus BUS di Indonesia. FEB UIN Syarif Hidayatullah, 4.

Rifai, A. (2016). Analisis Laporan Keuangan BMT Amanah Ummah. Surakarta: Fakultas Agama Islam Muhammadiyah Surakarta.

Rivai, V. (2013). Islamic Banking anda Finance. Yogyakarta: FEB UGM.

Riyanto. (2001). Dasar-dasar Pembelanjaan Perusahaan. Yogyakarta: BPFE.

Saliva, M. (2006). Analisis Laporan Keuangan Untuk Mengevaluasi antar Kinerja Perusahaan. Bandung: FE-Universitas Widytama.

Sari, K. (2015). Pengaruh CAR dan QR terhadap ROA pada bank umum syariah. Economics Journal, 26.

Simamora. (2012). Akuntansi Manajemen. Jakarta: Star Gate.

Soemarso. (2009). Akuntansi Suatu Pengantar. Jakarta: Salemba Empat.

Sofyan, S. H. (2008). Analisa Kritis atas Laporan Keuangan. Jakarta: Grafindo Persada.

Sugiyono. (2012). Metode Penelitian Kuantitatif, Kuantitatif, R\&D. Bandung: Alfabeta.

Sukmadinata, S. (2007). Metode Peneltian Pendidikan. Bandung: Remaja Rosdakarya.

Suwardjono. (2011). Teori Akuntansi Perekayasaan Laporan Keuangan. Yogyakarta: BPFE.

Syarifuddin. (2010). Kebijakan Anggaran: Aksentuasi Drama dan Politik Kekuasaan. Malang : Universitas Brawijaya.

Vertizhal Rivai, R. I. (2013). Islamic Risk Management for Islamic Bank. Jakarta: Kompas Gramedia. 